\title{
Protective role of nitric oxide in ocular toxoplasmosis
}

\author{
Seiji Hayashi, Chi-Chao Chan, Ricardo T Gazzinelli, NamTran H Pham, Margaret K \\ Cheung, Francois G Roberge
}

\begin{abstract}
Aims-To evaluate the role of nitric oxide (NO) in ocular involvement during systemic toxoplasmosis.

Methods-C57B1/6 mice were infected with Toxoplasma gondii strain ME49. The synthesis of NO was inhibited by an intraperitoneal injection of aminoguanidine every 8 hours, starting on the day of infection. Control infected mice received phosphate buffered saline vehicle alone. After 14 days, the ocular lesions were evaluated by histopathological examination. The expression of NO synthase induced in the spleen by toxoplasma infection was evaluated by immunostaining. The production of NO by the spleen cells of infected mice was measured by the colorimetric assay of Griess in the supernatant of cultures stimulated with toxoplasma antigen or concanavalin $\mathbf{A}$.
\end{abstract}

Results-The inhibition of NO production in $T$ gondii infected mice resulted in a marked increase in the symptoms of ocular inflammation. We observed a strong induction of NO synthase expression in the spleen of infected animals. In culture, the spleen cells from these mice produced high levels of NO in response to $T$ gondii antigens. This elevation of NO synthesis was suppressed in the presence of aminoguanidine.

Conclusion-This study indicates that NO plays a crucial role in the protection against $T$ gondii infection as reflected by the severity of the ocular involvement. (Br f Ophthalmol 1996;80:644-648)

Ocular toxoplasmosis is one of the most common diseases responsible for severe visual impairment. It represents $30 \%$ to $50 \%$ of posterior uveitis in the USA. ${ }^{1}$ It is caused by the intracellular protozoan Toxoplasma gondii. The ocular lesion usually consists of a localised area of necrotising retinochoroiditis associated with mild to severe overlying vitritis. ${ }^{2-4}$ Retinal infection is considered to follow a transplacental transmission in most cases, but may be acquired later in life by ingestion of contaminated food..$^{5-7}$
The resistance to $T$ gondii infection primarily involves macrophages activated by $\mathrm{T}$ cell lymphokines such as interferon $\gamma$. Oxygen radicals and cytotoxic $T$ cells also participate in the defence against $T$ gondii. ${ }^{8-10}$ Reactive nitrogen radicals were also recently observed to play an important part in the killing of intracellular protozoa in macrophage cultures. ${ }^{11}{ }^{12}$ Nitric oxide (NO) production, derived from the oxidation of L-arginine, is catalysed by the enzyme nitric oxide synthase. An inducible isoform of this enzyme is expressed in various cell types after stimulation by inflammatory cytokines and invasion by intracellular infectious agents. ${ }^{13}$ High levels of NO were shown to be produced by this mechanism in mouse macrophages as well as in human Müller and retinal pigment epithelial cells. ${ }^{11}{ }^{14} 15$

The present study was undertaken to assess the role of NO in $T$ gondii infection, as reflected in the evolution of the ocular disease in a mouse model of toxoplasmosis. The model is initiated by the injection of $T$ gondii ME49 strain in susceptible C57BL/6 mice. ${ }^{16}$ The infection causes a retinochoroiditis evolving from 2 to 4 weeks and characterised by an inflammatory infiltration of the retina, choroid, and vitreous. The inflammation results in retinal tissue damage followed by chorioretinal scarring and retinal pigment epithelial cell migration. ${ }^{16}$ In this model the parasite is often undetectable in the eye, and the extent of inflammation is used as a surrogate variable to assess the spread of the disease. In the present report we evaluated the role of NO in $T$ gondii infection by inhibiting NO synthesis with aminoguanidine, a structural analogue of L-arginine. ${ }^{17}$ The induction of NO synthase expression in the leucocytes of infected mice was examined by immunostaining of their spleens. The production of NO was measured in cultures of the spleen cells.

\section{Materials and methods}

ANIMAL MODEL AND TREATMENT EVALUATION C57BL/6 (B6) female mice (Jackson Laboratories, Bar Harbor, ME, USA) 6 to 8 weeks old were infected with $T$ gondii strain ME49 by intraperitoneal injection of 10 to 20 cysts, prepared by homogenisation of the brain of 

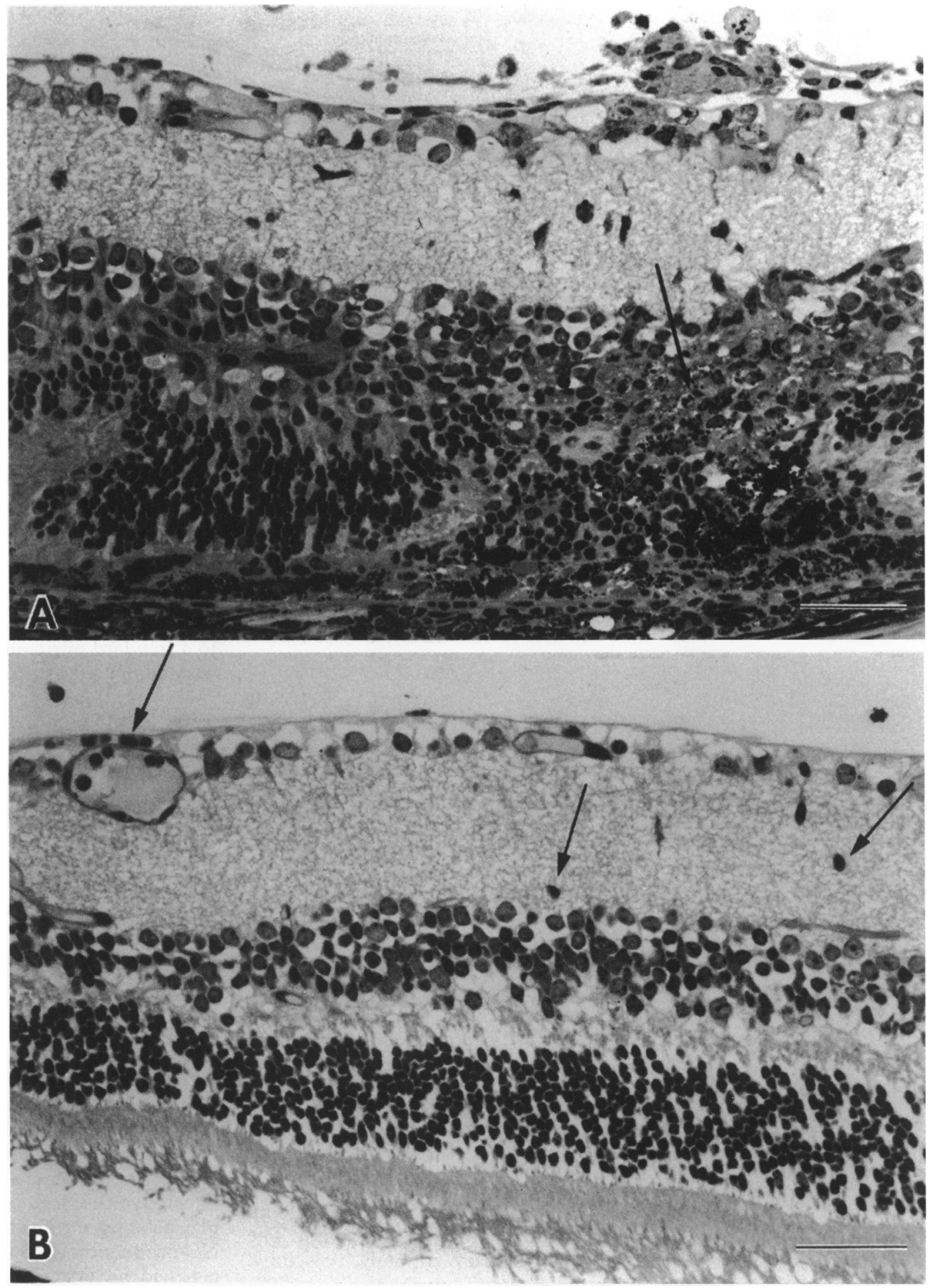

Figure 1 Histopathological sections of eyes from mice infected with Toxoplasma gondii. (A) Inflammatory cells infiltrating the choroid, the retina, and the vitreous of a mouse treated with aminoguanidine at $35 \mathrm{mg} / \mathrm{kg}$ every 8 hours for 14 days (arrow indicates a tachyzoite). (B) Eye of a control mouse treated with vehicle only (arrows indicate inflammatory cells). Haematoxylin and eosin staining. Bars indicate $30 \mu \mathrm{m}$.

chronically infected B6 mice as described elsewhere. ${ }^{16}$ The animals were housed in sterile cages and cared for according to the ARVO statement for the use of animals in ophthalmic research. The mice were divided into two groups of 20 animals treated with aminoguanidine at $35 \mathrm{mg} / \mathrm{kg}$ (Sigma Chemical, St Louis, MO, USA) or phosphate buffered saline (PBS) vehicle control starting on the day of infection and given by intraperitoneal injection of $100 \mu \mathrm{l}$ every 8 hours for 14 days. Ten non-infected mice also received aminoguanidine to rule out a direct effect of the drug. At the end of the treatment period the eyes were collected, fixed in $10 \%$ buffered formalin, and embedded in methacrylate. Histopathological sections cutting through the pupillary-optic nerve plane were stained with haematoxylin and eosin to evaluate the inflammation, and periodic acid Schiff (PAS) base to identify toxoplasma organisms. Retinitis and choroiditis were graded as previously described: $1+=$ one or two foci of inflammatory cell infiltration, each less than $100 \mu \mathrm{m}$ in length, $2+=$ one or two foci, between 100 and $200 \mu \mathrm{m}$ in length, $3+=3$ or 4 foci of less than $200 \mu \mathrm{m}$ in length, and 

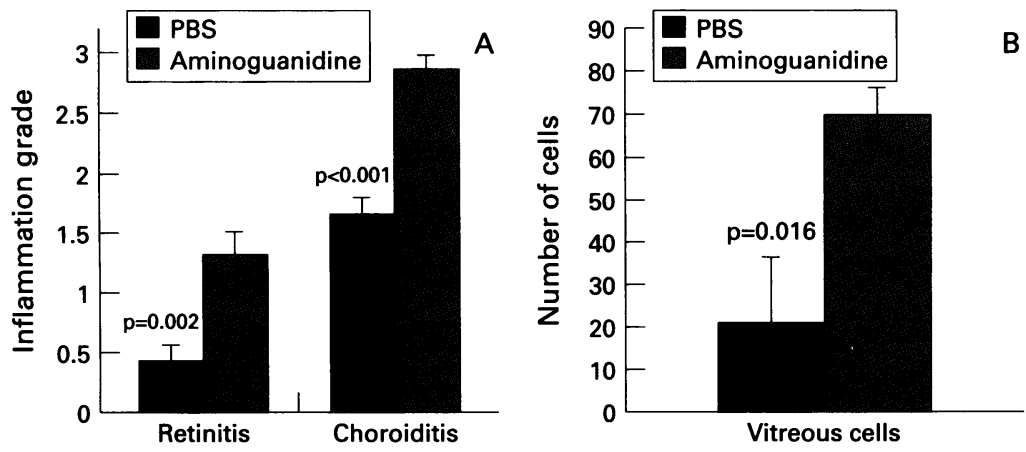

Figure 2 Effect of inhibition of NO production in toxoplasma infected mice treated with aminoguanidine or PBS for 2 weeks. (A) Histopathological grading of the retinal and choroidal inflammation on a scale of 0 to 3 , and $(B)$ vitreous cell number.

$4+=$ more extensive lesions in which foci are generally confluent. ${ }^{16}$ Vitreous inflammation was evaluated by counting the number of inflammatory cells.

Statistical analysis of the results was done using the Mann-Whitney $U$ test for two independent samples. A conservative $p$ value of less than 0.02 was used to reject the null hypothesis. The mean grade of the severity of tissue inflammation is also given as a descriptive value of data estimation.

IMMUNOSTAINING

Spleens were collected from naive mice and from mice infected 14 days previously with $T$ gondii. The tissue was fixed in $10 \%$ buffered formalin for 20 hours and progressively dehydrated in ethanol starting from a $50 \%$ concentration. Paraffin embedded $5 \mu \mathrm{m}$ sections were cut on silanated slides. The sections were deparaffinised with a mixture of Hemo-De (Fisher Scientific, Pittsburg, PA, USA) and xylene $3 / 1 \mathrm{v} / \mathrm{v}$ followed by ethanol. ${ }^{18}$ The slides were then boiled for 14 minutes in $10 \mathrm{mM}$ citrate buffer $\mathrm{pH} 6.0$ in a microwave oven set at $1000 \mathrm{~W}$, and allowed to cool for 30 minutes. ${ }^{19} 20$ Non-specific antibody binding sites were blocked with a 1 hour incubation at $37^{\circ} \mathrm{C}$ with $5 \%$ normal goat serum in $50 \mathrm{mM}$ TRIS- $\mathrm{HCl}$ normal saline buffer $\mathrm{pH} 7.5+$ $0.05 \%$ Tween-20, and $+20 \mathrm{mM}$ L-lysine (TBS-T-L). Labelling was done in the same buffer but containing $\mathrm{NaCl}$ at $3 \mathrm{~g} / 100 \mathrm{ml}$ (TBHS-T-L) and $2 \%$ normal goat serum. The steps were: (1) primary antibody, polyclonal affinity purified rabbit anti-iNOS (Transduction Laboratories, Lexington, KY, USA) $1: 100$, overnight at $4^{\circ} \mathrm{C}$; (2) secondary antibody, biotin labelled goat antirabbit (Kirkegaard \& Perry, Gaithersburg, MD, USA) 1:200 1.5 hours at $22^{\circ} \mathrm{C}$; (3) streptavidin-alkaline phosphatase $1: 1000,30$ minutes at $22^{\circ} \mathrm{C}$. In between steps, slides were washed in TRIS buffer pH 7.5 containing $50 \mathrm{mM}$ TRIS base, $0.25 \% \mathrm{v} / \mathrm{v}$ acetic acid, $1 \%$ ethanol, $0.05 \%$ Tween-20, and $30 \mathrm{mg} \%$ Brij-35. The slides were developed with fast red $\mathrm{TR} /$ naphthol phosphate (Research Genetics, Huntsville, AL, USA), washed in distilled water containing 30 $\mathrm{mg} / 100 \mathrm{ml}$ Brij-35 (DW-Brij), counterstained for 2 minutes in haematoxylin (Research Genetics), blued in TBS for 1 minute, washed in DW-Brij, and mounted in aqueous medium.
MEASUREMENT OF NO PRODUCTION BY SPLEEN

CELLS

Spleens from infected and naive mice were prepared to erythrocyte free single cell suspension. The cells were cultured at $2.5 \times 10^{6}$ cells/ml in phenol red-free RPMI 1640 (Bio Whittaker, Walkersville, MD, USA) containing $2 \mathrm{mM}$ of L-glutamine, $10 \%$ fetal bovine serum (Hyclone, Logan, UT, USA), and gentamicin $(50 \mu \mathrm{g} / \mathrm{ml})$. The cells were stimulated with 1.0 $\mu \mathrm{g} / \mathrm{ml}$ of concanavalin A (Boehringer Mannheim, Indianapolis, IN, USA) or $10 \mu \mathrm{g} / \mathrm{ml}$ of toxoplasma antigen prepared as described by Gazzinelli et $a l,{ }^{21}$ in the presence or absence of aminoguanidine $1.0 \mathrm{mM}$. The supernatants were collected after 72 hours of incubation at $37^{\circ} \mathrm{C}$ in an atmosphere of $5 \%$ carbon dioxide in air. NO production was evaluated by a colorimetric assay for the nitrite metabolite based on the Griess reaction. ${ }^{22}$ Briefly, $100 \mu$ of supernatant was reacted in a mixture of $50 \mu$ of $0.1 \% \mathrm{~N}$-(1-naphthyl)ethylene-diamine dihydrochloride and $50 \mu$ of $1.0 \%$ sulphanilamide in $3.0 \%$ phosphoric acid at room temperature. The absorbance was read after 5 minutes in a spectrophotometer at $540 \mathrm{~nm}$ with reference to a standard nitrite quantitative curve. Means were compared by Student's $t$ test.

\section{Results}

The inhibition of NO production with aminoguanidine in mice infected with $T$ gondii resulted in an enhancement of the ocular disease. On histopathological examination, the eyes of the infected mice treated with aminoguanidine showed increased inflammation as illustrated in Figure 1. The inflammation score in these mice compared with the infected controls was significantly augmented in the retina $(p=0.002)$, the choroid $(p<0.001)$, and the vitreous $(p=0.016)$ (Fig 2$)$. The eyes of non-infected mice treated with aminoguanidine were normal (data not shown).

Infection with $T$ gondii induced a strong expression of NOS in the spleen of the mice (Fig 3). As a competitor for the substrate of the enzyme, aminoguanidine does not affect NOS expression (data not shown). In culture of the infected mice spleen cells, the addition of toxoplasma antigen triggered a fourfold increase in NO production $(p<0.001)$ (Table 1$)$. The antigen had no effect on normal spleen cells. A small amount of NO was produced by the normal cells after non-specific stimulation with

Table 1 Production of nitric oxide by spleen cells from Toxoplasma gondii infected mice

\begin{tabular}{llrr}
\hline \multirow{4}{*}{ Sitrite $(\mu M)(S E M)$} \\
\cline { 2 - 4 } Spleen cells & Stimulant & \multicolumn{1}{l}{ Medium } & \multicolumn{1}{c}{ Aminoguanidine } \\
\hline Naive mice & None & $11.33(0.6)$ & $7.40(0.61)$ \\
& ConA & $21.09(1.03)$ & $11.38(0.69)$ \\
& Toxo Ag & $8.38(0.77)$ & $7.71(0.66)$ \\
Infected mice & None & $14.40(1.04)$ & $8.42(0.72)$ \\
& ConA & $50.76(1.60)$ & $13.95(0.87)$ \\
& Toxo Ag & $54.50(1.68)$ & $12.33(0.60)$ \\
\hline
\end{tabular}

Spleen cells at $2.5 \times 10^{6}$ cells $/ \mathrm{ml}$ were stimulated with toxoplasma antigen (Toxo Ag) $(10 \mu \mathrm{g} / \mathrm{ml})$ or concanavalin A (ConA) $(1.0 \mu \mathrm{g} / \mathrm{ml})$ in the presence or absence of aminoguanidine $(1.0$ $\mathrm{mM}$ ) for 72 hours. Nitrite accumulated in the supernatant was measured by the Griess colorimetric assay. Five mice per group. 


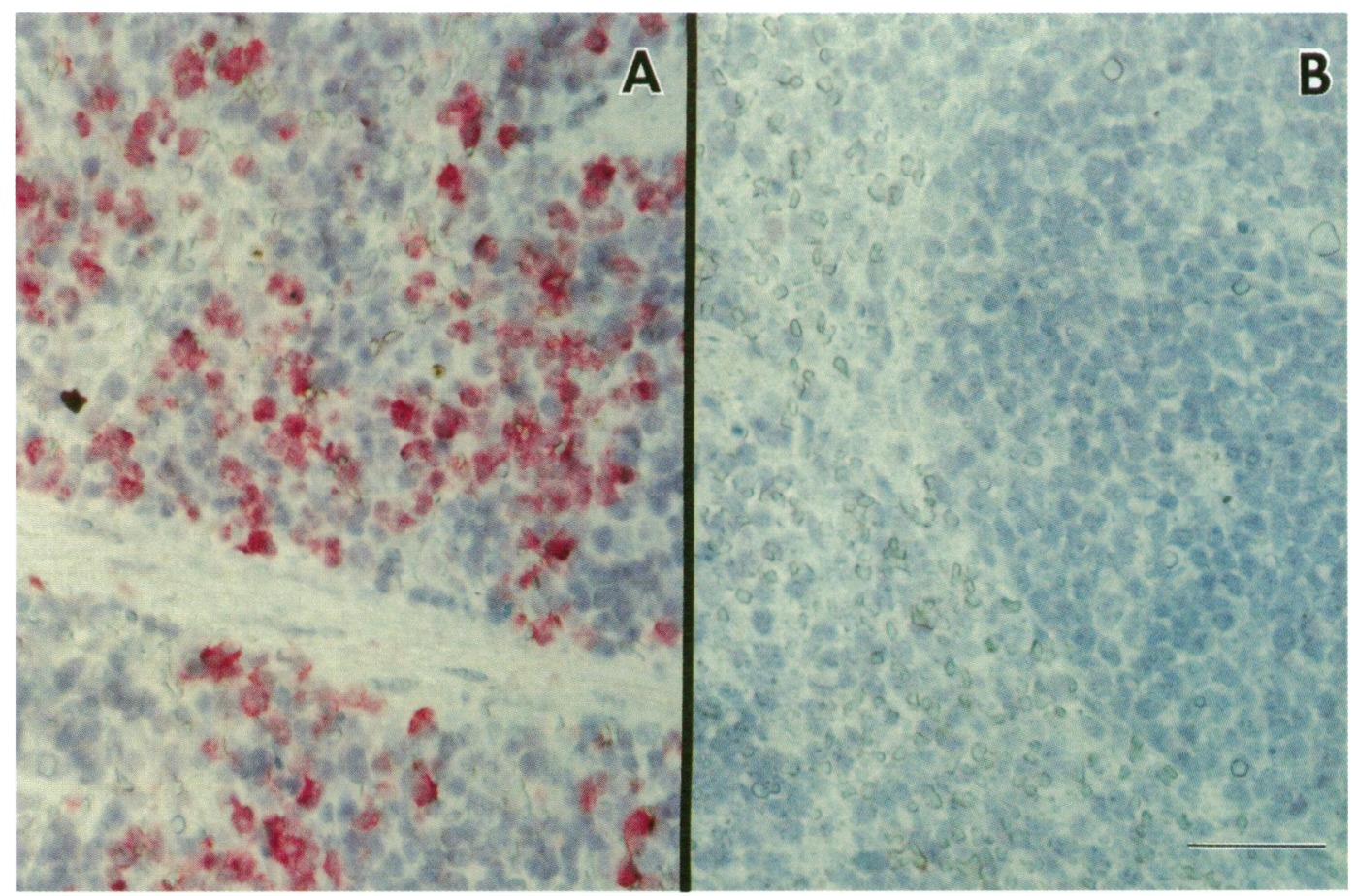

Figure 3 Immunoenzymatic staining of mouse spleens for inducible NO synthase. (A) Intense positive stain, seen in red, 14 days after Toxoplasma gondii infection. (B) Faint stain seen in the spleen of a normal non-infected mouse. Bar indicates $30 \mu \mathrm{m}$.

concanavalin A. However, the cells from infected mice secreted the same quantity of $\mathrm{NO}$ after concanavalin A stimulation than after antigenic stimulation, indicating that the larger part of the mechanism responsible for NO production had been induced in vivo by the toxoplasma infection. The synthesis of NO in these cultures was inhibited in the presence of aminoguanidine (Table 1).

\section{Discussion}

We have shown that immune cells from $T$ gondii infected mice are driven to produce high levels of NO, and that the in vivo inhibition of this response leads to severe damage to the eye by the infection. From these observations we conclude that endogenously produced NO plays a protective role against the development of ocular lesions in toxoplasmosis.

$T$ gondii is an obligate intracellular parasite. The ability to inhibit the replication of or to kill the organism is dependent on several metabolic pathways. ${ }^{93}$ The production of reactive nitrogen intermediates is now considered to be one of the most important means of intracellular microbial killing. ${ }^{24}{ }^{25}$ The activation of lymphocytes by toxoplasma laden macrophages leads to the production of a large array of lymphokines such as interferon $\gamma$, tumour necrosis factor $\alpha$, and interleukin 1 . In turn these cytokines were shown to mediate the signal for the production of NO by leucocytes. ${ }^{26-28} \mathrm{We}$ recently reported that the neutralisation of interferon $\gamma$ and tumour necrosis factor $\alpha$ with monoclonal antibodies dramatically enhances the ocular damage in C57BL/6 mice infected with $T$ gondii. ${ }^{16}$ In other models of infectious diseases such as leishmaniasis and listeriosis, a similar cycle of activating cytokines and NO production has been implicated in the immune response. $^{29}{ }^{30}$ In parallel with its cytotoxic effect on intracellular infective agent, NO has been shown to inhibit lymphocyte proliferation..$^{31-33}$ In our model we have also reported that NO production, induced in spleen cells of $T$ gondii infected mice, was responsible for this inhibition of the lymphocyte response. ${ }^{34}$ It was consequently assumed that the increase in the inflammatory response following treatment with aminoguanidine contributes to the enhanced severity of the lesions of toxoplasmosis.

The potential production of NO by ocular tissue cells during toxoplasma infection has not been studied yet. However, the inducible form of NO synthase was found to be expressed in the Müller cells of patients with cytomegalovirus retinitis. ${ }^{14}$ The human retinal pigment epithelium also produces NO in culture when stimulated by interferon $\gamma$ and interleukin $1 .^{15}$ These observations suggest that Müller cells and the retinal pigment epithelium may possibly participate in the local defence against $T$ gondii. The occurrence of toxoplasma retinochoroiditis during systemic corticosteroid treatment ${ }^{35}{ }^{36}$ and in AIDS patients ${ }^{37}$ could be related to an accompanying deficit of NO production in both of these conditions. In AIDS, the lymphokines required for NO production are reduced in proportion to the severe depletion in $\mathrm{T}$ cell number. ${ }^{38}$ The expression of the NO synthase gene is also inhibited by corticosteroids. ${ }^{39}$ It is a common practice to add corticosteroids to the antibiotic regimen in severe sight threatening toxoplasmosis. In view of the negative regulation of NO production by corticosteroids, the use of anti-inflammatory drugs devoid of effect on NO synthase should be considered. Future studies, examining the possibility and conditions of a local production of NO by organ specific cells as well as by infiltrating inflammatory cells during ocular 
toxoplasmosis, might help in the design of a more appropriate therapeutic management.

Dr Seiji Hayashi is sponsored by CNPq (National Council for Research), Brazil. We are grateful to Mrs Nicole Newman and Mr Reginald Gaskins for preparing our specimens for histopathological examination.

1 Krick JA, Remington JS. Toxoplasmosis in the adult-an overview. N Engl $\mathcal{Y}$ Med 1978;298:550-3.

2 Zimmerman LE. Ocular pathology of toxoplasmosis. Surv Ophthalomol 1961;6:832-8.

3 Rao NA, Font RL. Toxoplasmic retinochoroiditis. Arch Ophthalmol 1977;95:273-7.

4 Quinlan P, Jabs DA. Ocular toxoplasmosis. In: Schachat AP, Murphy RP, Patz A eds. Medical retina 1 ed. St Louis: Mosby, 1989:563-74.

5 Couvreur J, Desmonts G. Congenital and maternal toxoplasmosis. A review of 300 congenital cases. Develop toxoplasmosis. A review of 300 con

6 Glasner PD, Silveira C, Kruszon MD, Martins MC, Burnie JM, Silveira S, et al. An unusually high prevalence of ocular toxoplasmosis in southern Brazil. Am $\mathcal{f}$ Ophthalmo 1992;114:136-44.

7 Silveira C, Belfort RJ, Burnier MJ, Nussenblatt R. Acquired toxoplasmic infection as the cause of toxoplasmic retinochoroiditis in families. Am $\mathcal{F}$ Ophthalmol 1988;106:362-4

8 Murray HW, Juangbhanich CW, Nathan CF, Cohn ZA Macrophage oxygen-dependent antimicrobial activity. II The role of oxygen intermediates. $\mathcal{F}$ Exp Med 1979;150: 950-64.

9 Beaman MH, Wong SY, Remington JS. Cytokines, toxoplasma and intracellular parasitism. Immunol Rev 1992 127:97-117.

10 Hakim FT, Gazzinelli RT, Denkers E, Hieny S, Sheare GM, Sher A. CD8+ T cells from mice vaccinated against Toxoplasma gondii are cytotoxic for parasite-infected or antigen-pulsed host cells. F Immunol 1991;147:2310-6.

1 Adams LB, Hibbs JB, Taintor RR, Krahenbuhl JL. Microbiostatic effect of murine-activated macrophages for Toxoplasma gondii. $\mathcal{F}$ Immunol 1990;144:2725-9.

12 Nathan CF, Hibbs J. Role of nitric oxide synthesis in macrophage antimicrobial activity. Curr Opin Immunol 1991;3: 65-70.

13 Munoz FM, Fernandez MA, Fresno M. Activation of human macrophages for the killing of intracellular Trypanosoma cruzi by TNF-alpha and IFN-gamma Trypanosoma cruzi by TNF-alpha and IFN-gamma 1992;33:35-40.

14 Dighiero P, Reux I, Hauw J, Fillet AM, Courtois Y, Goureau O. Expression of inducible nitric oxide synthase in cytomegalovirus-infected glial cells of retinas from AIDS patients. Neurosci Let 1994;166:31-4.

15 Goureau O, Hicks D, Courtois Y. Human retinal pigmented epithelial cells produce nitric oxide in response to cytokines. Biochem Biophys Res Commun 1994;198:120-6.

16 Gazzinelli RT, Brezin A, Li Q Nussenblatt RB, Chan CC. Toxoplasma gondii: acquired ocular toxoplasmosis in the murine model, protective role of TN

gamma. Exp Parasitol 1994;78:217-29.

17 Corbett JA, Tilton RG, Chang $K$, Hasan KS, Ido $Y$, Wang $\mathrm{JL}$ et al. Aminoguanidine, a novel inhibitor of nitric oxide formation, prevents diabetic vascular dysfunction. Diabetes 1992;41:552-6.

18 Reed JA, Manahan LJ, Park C-S, Brigati DJ. Complete onehour immunocytochemistry based on capillary action. Bio Techniques 1992;13:434-43.

19 Shi S-R, Key ME, Kalra KL. Antigen retrieval in formalinfixed, paraffin-embedded tissue: an enhancement method for immunohistochemical staining based on microwave oven heating of tissue sections. F. Histochem Cytochem 1991, 39:741-8.
20 Munakata S, Hendricks JB. Effect of fixation time and microwave oven heating time on retrieval of the $\mathrm{Ki}-67$ antigen from paraffin-embedded tissue. 7 Histochem Cytochem 1993;41:1241-6.

21 Gazzinelli RT, Hakim FT, Hieny S, Shearer GM, Sher A Synergistic role of CD4+ and CD8+ T lymphocytes in IFN-gamma production and protective immunity induced by an attenuated Toxoplasma gondii vaccine. F Immunol 199i;146:286-92.

22 Ding AH, Nathan CF, Stuehr DJ. Release of reactive nitrogen intermediates and reactive oxygen intermediates from mouse peritoneal macrophages. Comparison of activating cytokines and evidence for independent production. Immunol 1988;141:2407-12.

23 Murray HW, Cohn ZA. Macrophage oxygen-dependent antimicrobial activity. I. Susceptibility of Toxoplasma gon-

24 Granger DL, Hibbs J, Perfect JR, Durack DT. Specific amino acid (L-arginine) requirement for the microbiostatic activity of murine macrophages. $\mathcal{f}$ Clin Invest 1988;81: activity of

25 Chan J, XingY, Magliozzo RS, Bloom BR. Killing of virulent Mycobacterium tuberculosis by reactive nitrogen intermediates produced by activated murine macrophages. $\mathcal{F}$ Exp Med 1992;175:1111-22.

26 Gazzinelli RT, Eltoum I, Wynn TA, Sher A. Acute cerebra toxoplasmosis is induced by in vivo neutralization of TNFalpha and correlates with the down-regulated expression of inducible nitric oxide synthase and other markers of macrophage activation. f Immunol 1993;151:3672-81.

27 Sibley LD, Adams LB, FukutomiY, Krahenbuhl JL. Tumor necrosis factor-alpha triggers antitoxoplasmal activity of necrosis factor-alpha triggers antitoxoplasmal activity of IFN-gan 2340 -5.

28 Suzuki Y, Orellana MA, Schreiber RD, Remington JS Interferon-gamma: the major mediator of resistance agains Toxoplasma gondii. Science 1988:240:516-8.

29 Evans TG, Thai L, Grager DL, Hibbs JB Jr. Effect of in vivo inhibition of nitric oxide production in murine leishmaniasis. F Immunol 1993;151:907-15.

30 Boockvar KS, Granger DL, Poston RM, Maybodi M, Washington MK, Hibbs JBJ, et al. Nitric oxide produced during murine listeriosis is protective. Infect Immun 1994;62:1089100.

31 Denham S, Rowland IJ. Inhibition of the reactive proliferation of lymphocytes by activated macrophages: the role of nitric oxide. Clin Exp Immunol 1992;87:157-62.

32 Schleifer KW, Mansfield JM. Suppressor macrophages in african trypanosomiasis inhibit $T$ cell proliferative reafrican trypanosomiasis inhibit $T$ cell proliferative re1993;151:5492-503.

33 Candolfi E, Hunter CA, Remington JS. Mitogen- and antigen-specific proliferation of $T$ cells in murine toxoplasmosis is inhibited by reactive nitrogen intermediates. Infect Immun 1994;62:1995-2001.

34 Hayashi S, Chan C-C, Gazzinelli R, Roberge FG. Contribution of nitric oxide to the host parasite equilibrium in toxoplasmosis. F Immunol 1996;156:1476-81.

35 O'Connor GR, Frenkel JK. Dangers of steroid treatment in toxoplasmosis. Periocular injections and systemic therapy. [Editorial] Arch Ophthalmol 1976;94:213.

36 Nicholson DH, Wolchok EB. Ocular toxoplasmosis in an adult receiving long-term corticosteroid therapy. Arch Ophthalmol 1976;94:248-54.

37 Parke DW 2d, Font RI Diffuse toxoplasmic retinochoroiditis in a patient with AIDS. Arch Ophthalmol 1986;104 tis in a

38 Murray HW, Rubin BY, Masur H, Roberts RB. Impaired production of lymphokines and immune (gamma) interferon in the acquired immunodeficiency syndrome. $N$ Engl f Med 1984;310:883-9.

39 Geller DA, Nussler AK, Di Silvio M,Lowenstein CJ Shapiro RA, Wang SC, et al. Cytokines, endotoxin, and glucocorticoids regulate the expression of inducible nitric oxide synthase in hepatocytes. Proc Natl Acad Sci USA 1993;90:522-6. 